\title{
Obituary
}

\section{Henri Paul André Saffrey, 1921-2021}

Henri Paul André Saffrey first trained as a scientist, attending the prestigious École Centrale. In 1944, he became a Dominican and took the religious name of Dominique. Henri Dominique Saffrey was initially a Latinist. Under the direction of Fr. Dondaine, Fr. Saffrey edited in 1954 the Commentary of St Thomas Aquinas on the Liber de causis, a book translated from Arabic into Latin and attributed to Aristotle, but whose content is inspired by Proclus' Éléments de Théologie, thus continuing the works of Fr. Chenu who had shown that Thomas' Platonism was just as significant as his Aristotelianism. The publication of Thomas' Commentaire in 1954, accompanied some years later by a major article on the Liber de causis, was followed in 1955 by a book on the fragments of Aristotle's De Philosophia, reissued in 2016 at the same time as a seminal article by Harold Cherniss. Fr. Saffrey went to study at Oxford with Professor E. R. Dodds, and in 1961 was awarded a doctorate in Philosophy, which was a critical review (with introduction, translation, and commentary) of book II of Proclus' Théologie Platonicienne. After that, he became 'Chercheur' at the CNRS (Paris) from 1962 to 1989 , as part of the Équipe de Recherche UPR 76 established and directed by Jean Pépin to which I had the honour and the privilege of belonging, along with Alain-Philippe Segonds, Joseph Combès and Marie-Odile and Richard Goulet.

Following in the footsteps of Fr. André Jean Festugière, in whose honour he published Mélanges with E. Lucchesi in 1984, Henri Dominique Saffrey leaves behind him a monumental body of scientific work. This was mainly devoted to the edition and the interpretation of major works of Greek Neoplatonism in Late Antiquity, after Plotinus, from the IV-VI centuries AD, from Porphyry to Damascius. His doctorate prepared him to undertake for the «Collection des «Universités de France», in collaboration with L. G. Westerink (eminent scholar in the fields of neoplatonic and byzantine philology) the colossal critical 
edition of Proclus' Théologie Platonicienne, of which six books were published in six volumes from 1968 to 1997. This collaboration having been interrupted by Westerink's death in 1990, the edition of volumes III-VI was shared with another scholar, Alain Philippe Segonds, who died in 2011. The introductions to the 6 volumes enable us to reconstitute the history of Athenian Neoplatonism. The prosopography of Proclus' entourage given in the Introduction of the first volume was the source of inspiration for the conception of the Dictionnaire des philosophes antiques published from 1989 onwards under the direction of his colleague from the CNRS, Richard Goulet, and we owe to Fr. Saffrey several entries on individual philosophers published in the first volumes of the Dictionary. To mark the completion of the Théologie Platonicienne, the whole neoplatonic community paid homage to these great masters who were Saffrey and Westerink in a seminar that took place in Louvain in 1998: Proclus et la Théologie Platonicienne, with the proceedings published in 2000 by Alain-Philippe Segonds and Carlos Steel, in collaboration with Concetta Luna.

In 1994, Fr. Saffrey published a translation of Proclus' Hymnes et Prières. To top it all, the Proclus ou Sur le bonheur, a eulogy delivered in April 486 by Marinus, Proclus' disciple, on the occasion of the first anniversary of the Master's death, was published (edition, translation and notes) in the Collection des Universités de France in 2001 by Fr. Saffrey and Alain-Philippe Segonds, together with Concetta Luna.

Finally, Fr. Saffrey published the fragments of the Lettre à Anebon by Porphyre (2012) and the Réponse à Porphyre known since Marsilio Ficino as the De mysteriis by Iamblichus (2013), the fine tuning of the volume having benefited from the editing work of Adrien Lecerf.

Fr. Saffrey enjoyed working with other researchers. His long collaboration with Alain-Philippe Segonds, as evidenced by weekly working sessions held at the Couvent Saint-Jacques, went back to the early Sixties, when Fr. Festugière was teaching the fifth section of the École Pratique des Hautes Études. Fr. Saffrey contributed to numerous publishing works, such as the ones of Joseph Combès, publisher- with Westerink- of Damascius.

In recent years, he even took care of the review of the 6th volume of the Commentaire de Proclus sur le Parménide, started by Alain-Philippe Segonds and Concetta Luna in 2007 and finished the same year by Concetta Luna with the publication of a $7^{\text {th }}$ volume; this edition of the Collection des Universités de France replaces, once and for all, the old Portus edition of 1618. And in 1985, with Jean Pépin, he organised at the CNRS the seminar Proclus, lecteur et interprète des anciens.

So far, this mainly concerns Proclus. However, one should also mention alchemy, bibliophilia, iconology, codicology, and the many other subject areas 
Fr. Saffrey was involved in. His contribution to the science of manuscripts and the study of the transmission, reception and interpretation of ancient texts is remarkable. A great number of his papers have been grouped in collections, notably in 1990 and 2000 in the two volumes dedicated to Neoplatonisme après Plotin and published by Vrin in the collection «Histoire des doctrines de l'Antiquité Classique» founded by Jean Pépin and directed nowadays by Luc Brisson. He also had a considerable interest in the history of humanism and other works on this subject have been collected in L'héritage des Anciens au Moyen-Âge et à la Renaissance published in 2002, in the same collection directed by Luc Brisson, as well as in Humanisme et imagerie aux XVe and $X V I e$ siècles published the following year. He also translated a few articles from English into French. Finally, let us mention his translation into French in 2016, of W. Kroll's seminal work on the Oracles Chaldaîques, written in exceedingly difficult Latin.

Henri Dominique Saffrey belongs to the family of great scholars who, in the second half of the 2oth century and the beginning of the 21st, have reinstated, through their knowledge as philologists, philosophers and historians, the multiple facets of the philosophical and theological thought and the spirituality of the last pagans in an ultimate resistance to the Christianisation of the Roman and Byzantine Empires. With the death of Fr. Saffrey, one of these great voices has disappeared. Let us hope that in future, his example will awaken new vocations.

PS. This obituary is based upon the text read by Philippe Hoffmann at the funeral of Fr. Saffrey (27 May 2021) and which will be published in French in the Revue des Sciences Philosophiques et Théologiques. Philippe Hoffman wishes to make clear that he was inspired both by a note written by Richard Goulet, Director of Research at the CNRS, who had himself talked about the person of Fr. Saffrey and his œuvre to the former Équipe of the latter, now the Centre Jean Pépin, and by an article written by Concetta Luna in the Review Academia, XIX, 2017.

\author{
Luc Brisson \\ Director of Research Emeritus \\ Centre Jean Pépin (UMR 8230 CNRS-ENS, PSL) \\ lbrisson@agalma.net
}

Translated by Elisabeth Planella 